\title{
JC virus agnoprotein colocalizes with tubulin
}

Shuichi Endo, Yuki Okada, Yasuko Orba, Hiroshi Nishihara, Shinya Tanaka, Kazuo Nagashima, and Hirofumi Sawa

Laboratory of Molecular and Cellular Pathology, Hokkaido University School of Medicine, Sapporo, Japan and CREST, Japan Science and Technology, Sapporo, Japan

The human polyomavirus JC (JCV) encodes an agnoprotein that consists of 71 amino acid residues, with a molecular weight of approximately $8 \mathrm{kDa}$, from the late protein coding region. The agnoprotein of JCV shares $50 \%$ to $60 \%$ homology with those of simian virus 40 (SV40) and BK virus (BKV), and the carboxyl-terminal region of JCV agnoprotein is relatively unique. By using specific antibody to the carboxyl-terminal region of JCV agnoprotein, the authors have demonstrated that JCV agnoprotein expressed in the JCV-infected cells, where it localized predominantly in the perinuclear region of the cytoplasm, and colocalizes with the cellular cytoskeletal protein, tubulin. The results suggest that JCV agnoprotein may play a role in the stability of microtubules and the preservation of JCV infected cells via an interaction with tubulin. Journal of NeuroVirology (2003) 9(suppl. 1), 10-14.

Keywords: agnoprotein; JC virus; tubulin

\section{Introduction}

The JC virus (JCV) genome encodes six proteins: the oncogenic early proteins large $\mathrm{T}$ and small $\mathrm{t}$ antigens, the viral capsid proteins VP1, VP2, and VP3, and agnoprotein. Although the virion of wild-type JCV consists of VP1, VP2, and VP3, including the viral minichromosomes, recombinant VP1, which is the largest capsid protein, with a molecular weight of $40 \mathrm{kDa}$, can self-assemble into capsid-like structures that are similar to authentic JCV virions (Goldmann et al, 1999; Ou et al, 1999). The 5' end of the JCV late region has the minimal open reading frame, which encodes a polypeptide of 71 amino acids, designated agnoprotein or leader protein (LP)-1 (Mertz et al, 1983). The JCV agnoprotein shares $58 \%$ and $54 \%$ of homology with those of simian virus 40 (SV40) and BK virus (BKV), respectively. The agnoproteins of SV40 and BKV appear to be confined to the peri-

Address correspondence to Hirofumi Sawa, MD, PhD, Laboratory of Molecular and Cellular Pathology, Hokkaido University School of Medicine, N15, W7, Kita-ku, Sapporo, 060-8638, Japan. E-mail: h-sawa@patho2.med.hokudai.ac.jp

The authors thank Dr. William W. Hall at the University College, Dublin, for the valuable suggestions, and Ms. Mayumi Sasada and Ms. Mami Sato for their excellent technical assistance. This study was supported in part by grants from the Ministry of Education, Science, Sports, Technology, and Culture, Japan.

Received 9 September 2002; accepted 28 October 2002. nuclear region of the cytoplasm of virus-infected cells (Nomura et al, 1983; Rinaldo et al, 1998). SV40 agnoprotein does not reside in the native virion and contributes to viral maturation, regulating transcription of the viral genome (Piatak et al, 1981; Alwine, 1982; Hay et al, 1982; Hay and Aloni, 1985), translation of late viral proteins, processing of viral proteins, and assembly of virions (Stacy et al, 1989). Recently, it has been reported that JCV agnoprotein functionally interacts with the viral early protein, large $\mathrm{T}$ antigen, and down-regulates viral gene expression and viral DNA replication (Safak et al, 2001). These data suggest that the polyomavirus agnoproteins may play important roles in viral proliferation within host cells.

We have reported that agnoprotein is expressed in JCV-infected cells and is distributed in cytoplasmic processes (Okada et al, 2001, 2002). The intracellular distribution pattern of agnoprotein prompted us to investigate whether JCV agnoprotein interacts with cellular cytoskeletal proteins. In this study, we report that JCV agnoprotein is bound to the cellular cytoskeletal protein, tubulin.

\section{Results}

Intracellular localization of JCV agnoprotein In order to analyze the intracellular localization of JCV agnoprotein, we have performed immunoblotting and immunocytochemical analysis of the 
JCV-producing cell line, JCI cells, which originated from the human neuroblastoma IMR-32 cells (Nukuzuma et al, 1995), using anti-agnoprotein antibody (Okada et al, 2001, 2002). Immunoblotting with anti-agnoprotein antibody revealed that agnoprotein was exclusively detected in JCI cells at $8 \mathrm{kDa}$ in size, whereas no signal was present in IMR-32 cells, which are the precursors of JCI cells (Figure 1a). Immunofluorescence staining revealed that agnoprotein mainly localized in the cytoplasm in the JCI cells and was present in the long cytoplasmic processes as a punctate staining pattern (Figure 1b). Double immunostaining analysis of JCV agnoprotein and the JCV capsid protein, VP1, with a laser scanning confocal microscope demonstrated that VP1 is predominantly detected in the nuclei, whereas agnoprotein localized in the perinuclear region and the cytoplasm with mesh-like staining pattern (Figure 1c). No immunopositve signal was present in the IMR32 cells (data not shown). These results suggested that JCV agnoprotein might interact with cytoskeletal proteins.

\section{Detection of JCV agnoprotein-binding protein(s)}

Because JCV agnoprotein is largely confined to the cytoplasm, and because proteins smaller than $60 \mathrm{kDa}$ cannot overcome passive diffusion within the cytosol without interactions with associated molecule(s), we have assumed that agnoprotein-binding protein(s) play a role in its cytoplasmic localization. To investigate this, JCI cells were grown in the methioninefree Dulbecco's minimum essential medium (DMEM) supplemented with $10 \%$ dialyzed fetal bovine serum (FBS) containing ${ }^{35} \mathrm{~S}$-labeled methionine. The cellular lysates were incubated with anti-agnoprotein antibody, and the mixture was bound to protein A-Sepharose beads. After washing, bound proteins were eluted from the beads, and subjected to SDSPAGE. Precipitated proteins were detected by autoradiography. The immunoprecipitation assay revealed five radioactive bands (approximately 52, 103, 112,132 , and $158 \mathrm{kDa}$ ), while nonspecific weak bands were also detected in lysates that were treated with rabbit immunoglobulin G (IgG) or beads only (Figure 2). The molecular weight of tubulin is $54 \mathrm{kDa}$. This result, together with the cytoplasmic localization of agnoprotein, prompted us to examine the relationship between agnoprotein and the cytoskeletal protein tubulin.

Double immunostaining of agnoprotein and tubulin To examine the localization of both agnoprotein and tubulin, agnoprotein was transiently expressed in the IMR-32 cells. Double immunostaining of JCV agnoprotein and tubulin revealed that exogenous JCV agnoprotein exclusively colocalized with tubulin in the cytoplasm and cytoplasmic processes (Figure 3). For use of anti-tubulin antibody, cells were fixed after detergent extraction performed under microtubulestabilizing conditions and processed for immunoflu- orescence. This method removes unassembled tubulin from the cell, so that the tubulin staining remaining in such cells can be attributable to the presence of microtubules (Gonzalez-Billault et al, 2001). Our findings strongly suggested that agnoprotein colocalized with microtubules in IMR-32 cells.

\section{Discussion}

Agnoprotein is encoded by SV40, BKV, and JCV, but not by murine polyomavirus. BKV agnoprotein was reported to bind cellular proteins with molecular masses of approximately 50, 75, and $100 \mathrm{kDa}$ (Rinaldo et al, 1998). We have shown that JCV agnoprotein was distributed in the perinuclear region, the cytoplasm, and the long cytoplasmic processes as punctate staining in JCI cells. Agnoproteins of BKV and SV40 have similar intracellular localizations as JCV (Rinaldo et al, 1998; Nomura et al, 1983). The expression of agnoprotein predominantly in the perinuclear and the cytoplasm led us to examine whether it interacts with cytoskeletal proteins. Immunocytochemical analysis suggested that JCV agnoprotein may interact with the cytoskeletal protein, tubulin, and modify its distribution and function in the cytoplasm of JCV-infected cells.

It has been recently reported that JCV agnoprotein interacts with viral large $\mathrm{T}$ antigen and downregulates viral gene expression and DNA replication in vitro (Safak et al, 2001). However, its cytoplasmic function has still not been fully investigated. Biochemical demonstration of the directed binding of the proteins and to define the domain within agnoprotein that are involved in the interaction with tubulin will be necessary for understanding the functional importance of the microtubule association (Endo et al, manuscript in preparation). The agnoprotein of JCV, $\mathrm{BKV}$, and SV40 have a highly homologous amino acid sequence in the amino-terminal regions. Together with their similar intracellular distribution, the data suggest that the binding motif against tubulin may also be located in the amino-terminal region.

\section{Materials and methods}

\section{Cell culture}

Human neuroblastoma cell line IMR-32 (JCRB 9050) was purchased from the Health Science Research Resources Bank (Tokyo, Japan). The IMR-32-derived JCV-producing cell line, JCI, was established by Dr. Nukuzuma (Nukuzuma et al, 1995). All cell lines were maintained in DMEM supplemented with $10 \%$ FBS, 2 mM L-glutamine (Sigma, St. Louis, MO), $1 \mathrm{mM}$ sodium pyruvate, $0.1 \mathrm{mM}$ nonessential amino acids, 50 units/ml penicillin and streptomycin (Gibco, Invitrogen, Carlsbad, CA) in humidified incubators with $5 \% \mathrm{CO}_{2}$ at $37^{\circ} \mathrm{C}$. Cells were grown on either collagen type-I-coated culture dishes (Iwaki, Tokyo, 
Figure 1 (a) Lysates of human neuroblastoma IMR-32 cells and JCV-infected IMR-32-derived JCI cells were subjected to immunoblot analysis using anti-agnoprotein antibody. The arrow indicates the signal of agnoprotein. (b) Immunostaining of agnoprotein of JCI cells. JCV agnoprotein (green) localized in the perinuclear region, the cytoplasm, and long cytoplasmic processes as a punctate pattern. (c) Double immunostaining of agnoprotein and JCV capsid protein VP1. Agnoprotein (green) was mainly recognized in the perinuclear region and in the cytoplasm, whereas VP1 (red) was localized in the nucleus.

Figure 2 Immunoprecipitation of JCI cell lysates using antiagnoprotein antibody revealed five radioactive bands around 52 , $103,112,132$, and $158 \mathrm{kDa}$, whereas no band was detected in samples that were treated with rabbit IgG or beads only. As the molecular weight of tubulin is $54 \mathrm{kDa}$, tubulin was considered to be a potential candidate for agnoprotein-binding protein.

Figure 3 Double immunostaining of JCV agnoprotein and tubulin. The merged image illustrates that JCV agnoprotein (green color) colocalized with the cytoskeletal protein tubulin (red color). 
Japan) or on poly-L-lysine-coated slide glasses (Muto Pure Chemica, Tokyo, Japan).

\section{Antibodies}

Polyclonal antibody specific to the JCV agnoprotein was produced to a synthetic peptide consisting of 24 amino acids corresponding to the carboxylterminal amino acid sequence (48-71) of the protein deduced from agnogene of the Mad1 strain of JCV (Frisque et al, 1984). New Zealand white rabbits were immunized with the peptide with an additional cysteine at its amino-terminus to facilitate the coupling to the carrier protein, keyhole limpet hemocyanin (KLH), as previously described (Okada et al, 2001). After immunization, the antibody was purified with an affinity column prepared by coupling the synthetic peptide to an N-hydroxysuccinimide (NHS)-activated Sepharose 4 FF (Amersham Pharmacia Biotech, Tokyo, Japan). Concentration of the purified antibody was determined from absorbance at $280 \mathrm{~nm}$ by using absorption coefficient of $1.34(\mathrm{mg} / \mathrm{ml})^{-1}(\mathrm{~cm})^{-1}$ (Hurn and Chantler, 1980). Biotinylated anti-agnoprotein antibody was prepared by using biotin (long arm) NHS ester (Vector Laboratories, Burlingame, CA) according to the manufacturer's instruction manual. Anti-VP1 antibody was generated by immunizing rabbits with virus-like particles prepared from recombinant VP1 expressed in Escherichia coli (Suzuki et al, 2001). Mouse monoclonal anti- $\mu$-tubulin (B-5-1-2) and rabbit IgGs were obtained from Sigma. Horseradish peroxidaseconjugated goat $\mathrm{F}\left(\mathrm{ab}^{\prime}\right)_{2}$ anti-mouse immunoglobulin (AMI4404) and horseradish peroxidase-conjugated goat $\mathrm{F}\left(\mathrm{ab}^{\prime}\right)_{2}$ anti-rabbit IgG (ALI4404) were obtained from Biosource International (Camarillo, CA). Alexa Fluor 488-conjugated goat anti-rabbit IgG, Alexa Fluor 594-conjugated goat anti-rabbit IgG and goat anti-mouse IgG, and Alexa Fluor 488-conjugated streptavidine were obtained from Molecular Probes (Eugene, OR).

\section{Immunocytochemistry}

JCI cells grown on poly-L-lysine coated slide glasses were fixed with methanol at $-30^{\circ} \mathrm{C}$ for $3 \mathrm{~min}$. For detection of tubulin, cells were treated with PHEM buffer [60 mM peperazine- $N, N^{\prime}$-bis(2-ethanesulfonic acid) (PIPES), $25 \mathrm{mM} \mathrm{N}$-(2-hydroxyethyl)piperazine$N^{\prime}$-(2-ethanesulfonic acid) (HEPES), $10 \mathrm{mM}$ EGTA, $2 \mathrm{mM} \mathrm{MgCl}_{2}, \mathrm{pH}$ 6.9] containing $0.2 \%$ saponin, $10 \mu \mathrm{M}$ paclitaxel, and $0.5 \%$ DMSO before methanol fixation (Gonzalez-Billault et al, 2001). Fixed cells were rehydrated in a washing solution (phosphatebuffered saline [PBS] containing $0.1 \%$ bovine serum albumin [BSA], $0.05 \%$ Tween 20 , and $0.1 \% \mathrm{NaN}_{3}$ ) for more than $5 \mathrm{~min}$. After incubation with a blocking solution (PBS containing 2\% BSA, 0.05\% Tween $20,0.05 \% \mathrm{NaN}_{3}, \mathrm{pH} 7.5$ ), cells were incubated with primary anti- $\mu$-tubulin antibody diluted in blocking solution for $30 \mathrm{~min}$. For double immunostaining against agnoprotein and $\mu$-tubulin, cells were coin- cubated with anti-agnoprotein $(1: 2000)$ and mouse monclonal anti- $\mu$-tubulin (1:1000) antibodies. After incubation with the washing solution, cells were incubated with secondary antibodies, including Alexa Fluor 488-conjugated goat anti-rabbit IgG and Alexa Fluor 594-conjugated goat anti-mouse IgG (1:400) for $30 \mathrm{~min}$. The cells were then rinsed with PBS, and mounted with mounting medium (Vectashield; Vector Laboratories). For double immunostaining with anti-agnoprotein and anti-VP1 antibodies, cells were initially incubated with anti-VP1 antibody (1:1000) and Alexa Fluor 594-conjugated goat anti-rabbit IgG (1:400), thereafter successively incubated with the biotinylated anti-agnoprotein (1:400) and Alexa Fluor 488-conjugated streptavidine (1:400).

\section{Metabolic labeling and immunoprecipitation}

JCI cells (at $80 \%$ to $90 \%$ confluence) were labeled for $16 \mathrm{~h}$ with $0.02 \mathrm{mCi} / \mathrm{ml}$ of $\mathrm{L}-\left[{ }^{35} \mathrm{~S}\right]$ methionine (Amersham Biosciences, Piscataway, NJ) in 90\% methionine-depeleted DMEM. After labeling, the cells were lysed in a lysis buffer [50 mM HEPES, $150 \mathrm{mM} \mathrm{NaCl}, 1 \mathrm{mM}$ EDTA, 1\% Triton X-100, 0.05\% $\mathrm{NaN}_{3}$, pH 7.4, containing protease inhibitors $(1 \mathrm{mM}$ phenylmethyl sulfonyl fluoride [PMSF], $1 \mu \mathrm{g} / \mathrm{ml}$ aprotinin, $2 \mu \mathrm{M}$ leupeptin, $2 \mu \mathrm{M}$ pepstatin, $0.5 \mathrm{mg} /$ $\mathrm{ml}$ Pefablock, $2 \mathrm{mM}$ benzamidine $\mathrm{HCl}, 0.1 \mathrm{mM}$ benzethonium $\mathrm{Cl}, 3 \mu \mathrm{g} / \mathrm{ml}$ trans-epoxysuccinyl-Lleucylamido-(4-guanidino)butane (E64), $20 \mu \mathrm{g} / \mathrm{ml}$ bestatin, $\mathrm{pH}$ 7.4) and phosphatase inhibitors (1 mM $\left.\mathrm{NaF}, 1 \mathrm{mM} \mathrm{Na}_{3} \mathrm{VO}_{4}\right)$ ] for $30 \mathrm{~min}$ on ice. After centrifugation at $20,000 \mathrm{rpm}$ at $4^{\circ} \mathrm{C}$ for $20 \mathrm{~min}$, the cell extract was subjected to immunoprecipitation with either purified anti-agnoprotein antibody or rabbit IgG. Immune complexes were recovered with a protein A-Sapharose 4FF, and subjected to sodium dodecyl sulfate-polyacrylamide gel electrophoresis (SDS-PAGE).

\section{SDS-PAGE and immunoblotting}

The cell lysates were mixed with the SDS sample buffer followed by sonication, thereafter analysed by SDS-PAGE using 17\% gel (Laemmli, 1970). Proteins transferred onto a polyvinyldifluoride (PVDF) membrane (Haid and Suissa, 1983) was incubated in blocking buffer $(5 \%[\mathrm{w} / \mathrm{V}]$ nonfat dry milk, $0.5 \%$ $[\mathrm{v} / \mathrm{v}]$ Tween-20, PBS, pH 7.5) overnight, and incubated with anti-agnoprotein antibody $(1: 2000)$ for more than $6 \mathrm{~h}$. After three washes with PBS containing $0.5 \%(\mathrm{v} / \mathrm{V})$ Tween 20 (PBS-T) for $10 \mathrm{~min}$, the membrane was incubated with horseradish peroxidaseconjugated second antibody (1:5000) for $2 \mathrm{~h}$. The signal was detected with the ECL reaction, and visualized with the LAS-1000 plus system (Fujifilm, Tokyo, Japan).

\section{Exogenous expression of agnoprotein in IMR-32 cells}

Recombinant agnoprotien was expressed in IMR-32 cells with the pSFV1 eukaryotic expression system (Invitrogen) according to the method described in the 
manufacturer's instruction manual. Briefly, cDNA of agnogene containing the Kozak sequence and AUG translation initiation site was subcloned into the Bam HI site of the pSFV1 vector. After linearization with Spe I, recombinant agno mRNA was transcribed by

\section{References}

Alwine JC (1982). Evidence for simian virus 40 late transcriptional control: mixed infections of wild-type simian virus 40 and a late leader deletion mutant exhibit trans effects on late viral RNA synthesis. J Virol 42: 798-803.

Frisque RJ, Bream GL, Cannella MT (1984). Human polyomavirus JC virus genome. J Virol 51: 458-469.

Goldmann C, Petry H, Frye S, Ast O, Ebitsch S, Jentsch KD, Kaup FJ, Weber F, Trebst C, Nisslein T, Hunsmann G, Weber T, Luke W (1999). Molecular cloning and expression of major structural protein VP1 of the human polyomavirus JC virus: formation of virus-like particles useful for immunological and therapeutic studies. J Virol 73: 4465-4469.

Gonzalez-Billault C, Avila J, Caceres A (2001). Evidence for the role of map1b in axon formation. Mol Biol Cell 12: 2087-2098.

Haid A, Suissa M (1983). Immunochemical identification of membrane proteins after sodium dodecyl sulfatepolyacrylamide gel electrophoresis. Methods Enzymol 96: 192-205.

Hay N, Aloni Y (1985). Attenuation of late simian virus 40 mRNA synthesis is enhanced by the agnoprotein and is temporally regulated in isolated nuclear systems. Mol Cell Biol 5: 1327-1334.

Hay N, Skolnik-David H, Aloni Y (1982). Attenuation in the control of SV40 gene expression. Cell 29: 183-193.

Hurn BA, Chantler SM (1980). Production of reagent antibodies. Methods Enzymol 70: 104-142.

Laemmli UK (1970). Cleavage of structural proteins during the assembly of the head of bacteriophage T4. Nature 227: 680-685.

Mertz JE, Murphy A, Barkan A (1983). Mutants deleted in the agnogene of simian virus 40 define a new complementation group. J Virol 45: 36-46.

Nomura S, Khoury G, Jay G (1983). Subcellular localization of the simian virus 40 agnoprotein. J Virol 45: 428433. the SP6 RNA polymerase in vitro and transfected with DMRIE-C Reagent into IMR-32 cells. Twentyfour hours later, transfected cells were fixed and subjected to double immunofluorescence analysis for agnoprotein and tubulin.

Nukuzuma S, Yogo Y, Guo J, Nukuzuma C, Itoh S, Shinohara T, Nagashima K (1995). Establishment and characterization of a carrier cell culture producing high titres of polyoma JC virus. J Med Virol 47: 370-377.

Okada Y, Endo S, Takahashi H, Sawa H, Umemura T, Nagashima K (2001). Distribution and function of JCV agnoprotein. J NeuroVirol 7: 302-306.

Okada Y, Sawa H, Endo S, Orba Y, Umemura T, Nishihara H, Stan AC, Tanaka S, Takahashi H, Nagashima K (2002). Expression of JC virus agnoprotein in progressive multifocal leukoencephalopathy brain. Acta Neuropathol (Berl) 104: 130-136.

Ou WC, Wang M, Fung CY, Tsai RT, Chao PC, Hseu TH, Chang D (1999). The major capsid protein, VP1, of human JC virus expressed in Escherichia coli is able to self-assemble into a capsid-like particle and deliver exogenous DNA into human kidney cells. J Gen Virol 80: 39-46.

Piatak M, Subramanian KN, Roy P, Weissman SM (1981). Late messenger RNA production by viable simian virus 40 mutants with deletions in the leader region. $J \mathrm{Mol}$ Biol 153: 589-618.

Rinaldo CH, Traavik T, Hey A (1998). The agnogene of the human polyomavirus BK is expressed. J Virol 72: 62336236.

Safak M, Barrucco R, Darbinyan A, Okada Y, Nagashima $\mathrm{K}$, Khalili K (2001). Interaction of JC virus agno protein with $\mathrm{T}$ antigen modulates transcription and replication of the viral genome in glial cells. J Virol 75: 1476-1486.

Stacy T, Chamberlain M, Cole CN (1989). Simian virus 40 host range/helper function mutations cause multiple defects in viral late gene expression. J Virol 63: 52085215.

Suzuki S, Sawa H, Komagome R, Orba Y, Yamada M, Okada Y, Ishida Y, Nishihara H, Tanaka S, Nagashima K (2001). Broad distribution of the JC virus receptor contrasts with a marked cellular restriction of virus replication. Virology 286: 100-112. 